\title{
KONCEPT AUTOKEFALIJE U PRAVOSLAVLJU NA PRIMJERU PRAVOSLAVNE CRKVE U UKRAJINI
}

\author{
Thomas Bremer
}

Katholisch-Theologische Fakultät

UDK: 271.222(477):271.2

Ökumenisches institut, Münster

th.bremer@uni-muenster.de

\author{
https://doi.org/10.34075/cs.54.4.7 \\ Pregledni znanstveni rad \\ Rad zaprimljen 3/2019.
}

\section{Sažetak}

Tijekom 2018. i 2019. godine crkvene su se prilike u ukrajinskom pravoslavlju bitno promijenile. Uz znatnu pomoć tadašnje ukrajinske vlade, Carigradska patrijaršija jednostrano je proglasila tek stvorenu "Pravoslavnu Crkvu Ukrajine" (PCU) autokefalnom, tj. samostalnom. Ruska Pravoslavna Crkva pak smatra Ukrajinu svojim "kanonskim teritorijem" i ne priznaje PCU valjanom, nego je naziva šizmatičnom organizacijom. Reagirajući na proglašenje autokefalnosti PCU, ruska je Crkva prekinula euharistijsko zajedništvo s Carigradom. Postoji čak opasnost šizme koja bi obuhvatila cijelo pravoslavlje, u ovisnosti o tome kako ce reagirati druge pravoslavne crkve. Aktualna rasprava posljedica je činjenice da u pravoslavlju ne postoji konsenzus o tome kako jedna Crkva može postati autokefalnom. U pozadini stoje ekleziološki problemi koji nisu riješeni. Pitanje autokefalnosti pravoslavna je tematika, ali i za Katoličku Crkvu i teologiju, posebno u njezinom trenutačnom položaju, važno je razmišljati o odnosu između sinodalnosti i prvenstva.

Ključne riječi: Ukrajina, Carigrad, Pravoslavna Crkva, autokefalnost, ekleziologija

\section{UVOD}

Pravoslavna Crkva organizirana je u “autokefalnim” Crkvama, od kojih danas 14 njih priznaju sve ostale. Međutim, već o broju samostalnih crkava ne postoji suglasnost, kao ni o načinu kako jedna Crkva može postati autokefalnom, niti o uvjetima koji za dobivanje autokefalnosti moraju biti ispunjeni. O tom pitanju prošle je godine (2018.) nastao oštar konflikt između prve po rangu Crkve, Carigradske (Ekumenske ili Vaseljenske) patrijaršije, i najveće pravoslavne Crkve, Moskovske patrijaršije. Konkretno se radilo o pitanju statusa Pravoslavne Crkve u Ukrajini. Dok je postojao Sovjetski 
Savez ili prije njega Rusko Carstvo, pravoslavci u Ukrajini spadali su pod jurisdikciju Ruske Pravoslavne Crkve (RPC). U kontekstu raspada komunističke države i osamostaljenja Ukrajine nastale su nove crkve, koje su dugo vremena bile nekanonske. Ekumenska patrijaršija (EP) pokušala je riješiti tu situaciju, što je dovelo do novih konflikata. Ta je rasprava tema ovog izlaganja. Međutim, sinodalnost i jačanje lokalnih Crkava tema je i u trenutačnom pontifikatu u Katoličkoj Crkvi. Premda ona ima drugačiju strukturu od Pravoslavne, ipak valja razmišljati o konceptu autokefalnosti i s katoličkoga gledišta, što ćemo izložiti u trećem dijelu ovog teksta.

\section{CRkvena SituaciJa U UkRAJini}

Krajem desetog stoljeća kršćanstvo je u svojem istočnom obliku došlo u prostore današnje Ukrajine. Tada je postojao savez kneževina koji se zvao Rus' ili Kijevska Rus', budući da je u Kijevu bilo sjedište velikog kneza. U kontekstu političkih procesa Rus' se približavala Bizantskom Carstvu, i primila kršćanstvo, najvjerojatnije 988. godine. Kijevski mitropolit bio je u jurisdikciji EP-a i bio je ili poslan iz Carigrada ili izabran u Kijevu i potvrđen u Carigradu. Poslije su bile osnovane i druge biskupije koje su preko mitropolita bile povezane s Carigradom.

Kad su Tatari s istočne strane i Litva sa zapadne napadali Rus', značenje Kijeva se umanjilo i težište Rusi pomaklo se prema sjeveru, u današnju Rusiju. Prijestolnicom je postao najprije grad Vladimir, a poslije, u 14. stoljeću, Moskva. Mitropoliti su se preselili u novu prijestolnicu, ali su sačuvali naslov "kijevski”. Sam Kijev je s vremenom pao pod litavsku vlast. Kratkotrajno su Litavci imali svojeg pravoslavnog mitropolita u Kijevu tako da su postojala dva mitropolita s istim naslovom, jedan u Moskvi, a jedan u Kijevu. U ruskoj i ukrajinskoj historiografiji taj se proces danas tumači posve različito. Dok Rusi tvrde da se radilo o nečemu poput translatio imperii, dakle o prenošenju vlasti na drugo mjesto, i time naglašavaju kontinuitet, Ukrajinci naglašavaju kijevski kontinuitet i kažu da je na sjeveru nastalo nešto novo, ali da je kijevska tradicija ostala u Kijevu. Obje strane imaju svoje jake argumente, tako da se taj konflikt ne može riješiti povijesnim činjenicama. ${ }^{1}$ No razumljivo je da Kijev ima veliko značenje za rusku crkvenu i svjetovnu povijest.

\footnotetext{
1 Vidi opširnije: Thomas Bremer - Sophia Senyk, The Current Ecclesial Situation in Ukraine. Critical Remarks, St Vladimir's Theological Quarterly 63 (2019.) 1, 27-58.
} 
Sredinom 15. stoljeća Carigradska je Crkva na Koncilu u Firenci sklopila kratkotrajnu uniju s Rimskom Crkvom. Kijevski (zapravo moskovski) mitropolit Izidor bio je pristaša unije. On je bio Grk iz Carigrada, a mitropolitom je imenovan netom prije početka Koncila; kratko je boravio u Moskvi i onda otputovao u Italiju na Koncil. Kad je nakon povratka s Koncila pokušao provesti uniju u Moskvi, bio je uhićen i morao je napustiti zemlju. Moskovska Crkva našla se u neprilici jer je Carigradska Crkva, koja je trebala imenovati novog mitropolita, bila pala u krivovjerje (zbog unije s Rimom). Zbog toga su Rusi sami izabrali svog mitropolita, ne tražeći potvrdu iz Carigrada, koji se potom nazvao "moskovskim". Time je RPC postala "autokefalnom", to jest samostalnom Crkvom. EP se poslije pomirila s tim i pristala je da se RPC uzdigne na rang patrijarhata. Bilo je to prvi put nakon antičkog doba da je jedna Crkva dobila taj rang.

Godine 1686. grad Kijev i istočni dio današnje Ukrajine politički potpadaju pod moskovsku vlast. Obje Crkve, dakle Carigradska i Moskovska patrijaršija dogovorile su se da moskovski patrijarh ima pravo imenovanja novih mitropolita, ali da su oni obvezni u liturgiji komemorirati carigradskog patrijarha. Taj dogovor ubrzo je pao u zaborav, a RPC je zapravo preuzela jurisdikciju nad (pravoslavnom) Ukrajinom. Tako je ostalo i u Ruskom Carstvu te poslije u Sovjetskom Savezu i nakon njegova raspada, sve do ljeta 2018. godine, a da EP to nikad nije osporila. Još prije osamostaljenja Ukrajine tamošnje se pravoslavlje raspalo na tri Crkve. Najveća se zvala Ukrajinska Pravoslavna Crkva (UPC). Ona je nastala iz RPC-a u Ukrajini. Njezin mitropolit je ex officio član Svetog sinoda RPC-a, dakle najvišeg tijela te Crkve; zato je bila u zajednici s Moskvom i time sa svim pravoslavnim crkvama. Pri kraju postojanja Sovjetskog Saveza ona je od Moskve dobila široka prava i naziva se "samoupravnom Crkvom". To znači da ona sama bira svog poglavara (kijevskog mitropolita), koji biva "blagoslovljen" (dakle ne potvrđen!) od moskovskog patrijarha. Ona sama bira i svoje episkope.

Još u vrijeme nakon revolucije godine 1917. osnovana je Ukrajinska autokefalna Pravoslavna Crkva (UAPC). Nju su činili svećenici i laici, no nijedan episkop nije ju priznao, tako da je ostala nekanonska, budući da su svećenici zaredili jednog iz svojih redova za episkopa, bez biskupske sukcesije. Iako su je sovjetske vlasti najprije podupirale (kao protutežu RPC-u), ona je nestala u općom teroru tridesetih godina 20. st. No za vrijeme okupacije u Drugom svjetskom ratu njemačke vojne vlasti pridobile su episkope iz emigracije i uz njihovu pomoć reorganizirale UAPC, ovaj put s valjanom sukcesijom. Nakon poraza Nijemaca episkopi su se s mnogim svećenicima i laicima povukli na Zapad i ondje osnovali svoju Crkvu, posebno 
u SAD-u i u Kanadi. Episkopi su se poslije podredili carigradskom patrijarhu. Kad je politička represija u Sovjetskom Savezu popustila, predstavnici UAPC-a došli su u Ukrajinu i ondje, bez suglasnosti EP-a i protiv volje Moskve, osnovali svoje eparhije (biskupije). Time su od 1990. postojale dvije pravoslavne crkve u zemlji, kanonska UPC i nekanonska UAPC.

Dugogodišnji kijevski mitropolit Filaret tada je tražio od RPC-a potpunu autokefalnost (samostalnost) za ukrajinsko pravoslavlje. Kad to nije dobio, najprije se povukao, a onda je zajedno s nekim episkopima UPC-a prešao u UAPC i preimenovao je u Ukrajinsku Pravoslavnu Crkvu - Kijevsku patrijaršiju (UPC-KP). Ni ta Crkva naravno nije bila kanonska. Uskoro je došlo do sukoba, a dio episkopa UAPC-a napustio je tu novu organizaciju i vratio se svojoj dotadašnjoj Crkvi. Nakon nekoliko godina Filaret je postao "patrijarhom" UPC-KP-a.

Takva je situacija bila do 2018. godine: postojale su tri pravoslavne Crkve, od kojih je samo jedna bila kanonska i time dio "službenog" svjetskog pravoslavlja. Ostale pravoslavne Crkve, dakle Grčka, Srpska, Bugarska itd., održavale su kontakte samo s tom Crkvom, a i Katolička Crkva je samo nju priznala. ${ }^{2}$ UAPC i UPC-KP pokušale su se nekoliko puta ujediniti, no to se nije ostvarilo, ponajprije zato što je "patrijarh" Filaret tražio da on ostane u svojoj funkciji i da ujedinjena Crkva nosi ime Kijevskog patrijarhata. Filaret (koji je početkom 2019. godine napunio 90 godina) bio je od 1966. episkop kijevski u sustavu RPC-a i najočitije je surađivao s tadašnjim vlastima. Za vrijeme komunizma on je $u$ inozemstvu tvrdio kako nema vjerskog proganjanja u Sovjetskom Savezu, a isto tako da se Grkokatolička Crkva 1946. dobrovoljno "vratila" u RPC te da više ne postoji (premda je bilo poznato da je djelovala u tajnosti). Zbog te svoje osobne povijesti Filaret nije bio povoljan partner za pravoslavce u Ukrajini koji su tražili autokefalnu Crkvu, premda je on nakon osamostaljenja Ukrajine naglašavao svoje ukrajinsko podrijetlo.

Teško je govoriti o veličini tih Crkava. Raspolažemo pouzdanim podatcima Ministarstva unutarnjih poslova Ukrajine koje godinama vodi evidenciju o broju parohija (župa) svake vjerske zajednice

2 Katolička Crkva uvijek je naglašavala da je priznanje neke crkve kanonskom unutarnja stvar pravoslavlja i da će ona priznati one crkve kao pravoslavne koje svjetsko pravoslavlje priznaje. Kad je papa Ivan Pavao II. posjetio Ukrajinu 2001., on se nije susretao s predstavnicima nekanonskih crkava. Neki od njih bili su prisutni na susretu pape sa Sveukrajinskim vijećem crkava i vjerskih zajednica, ali nije došlo to bilateralnih kontakata. Međutim, Ukrajinska Grkokatolička Crkva često je podupirala ekumenske kontakte s nekanonskim crkvama. 
u zemlji. Prema podacima iz 2017. UPC je bila najveća, sa 12.348 župa. UPC-KP imala je 5167 župa, dok je UAPC-u pripadalo 1167 župa (Grkokatolička Crkva je imala 3433, a Rimokatolička 937 župa). ${ }^{3}$ Prema tome, UPC je bila najveća, čak veća od svih ostalih pravoslavnih crkava zajedno. Treba međutim uzeti u obzir da je po ukrajinskom zakonu o vjerskim zajednicama relativno lako osnovati župe, a relativno teško ugasiti ih. U prvim godinama nakon komunizma sve su Crkve osnovale župe kako bi bile prisutne posvuda, a nije sigurno koliko njih danas zaista postoji. Osim toga broj župa ne govori o broju vjernika. Crkva na selu u koju nedjeljom odlazi desetak ljudi u ovoj je statistici jedna župa, kao i katedralna crkva, u kojoj se održavaju tri liturgije svake nedjelje i na koje dolazi po 400 vjernika. Sociolozi su pokušali provesti ankete kako bi utvrdili broj vjernika svake Crkve. Ali svi su ti podaci nepouzdani; kad se samo promijeni redoslijed Crkava u anketi, rezultat je drukčiji (one Crkve koje su na vrhu liste dobivaju više "vjernika"). Mnogi od anketiranih i ne znaju kako se zove Crkva kojoj pripadaju ili se jednostavno izjašnjavaju kao "pravoslavci".

Podaci o broju župa i odnos među tim brojkama ostali su nepromijenjeni u zadnjih dvadesetak godina, premda je apsolutni broj narastao. Nakon prosvjeda na Majdanu u studenome 2013., okupacije i aneksije Krima 2014. i rata na istoku zemlje, neke župe su prešle iz svoje Crkve u neku novu, uglavnom iz UPC-a u UPC-KP. Mediji su izvještavali da se pritom katkad radilo i o nasilju, no to se ne može sa sigurnošću utvrditi. Ali i tu je riječ o 20 do 30 župa godišnje, tako da prijelazi nisu znatno utjecali na brojčane odnose. Od godine 2014. teško je ili nemoguće utvrditi broj župa na Krimu i u Donbasu, tako da su podaci za te dijelove Ukrajine nepouzdani.

Od samostalnosti Ukrajine 1991. gotovo sve vlade i svi predsjednici pokušali su, s jedne strane, održavati ravnotežu između Crkava, a s druge podržavati Crkve "ukrajinske orijentacije". Tako je svaka Crkva imala jednu reprezentativnu zgradu (crkvu) u Kijevu, a povijesna katedrala sv. Sofije nije pripala ni jednoj, nego je bila muzej u vlasništvu države koji se katkad koristio za državne priredbe. Na Dan neovisnosti vodstvo države i poglavari svih Crkava okupili bi se ondje na svečanoj proslavi. Država je inicirala "Sveukrajinsko vijeće crkava i vjerskih zajednica" u kojemu su predstavnici svih crkava i zajednica s predstavnicima vlasti surađivali na pitanjima od zajedničkog interesa. Intervencija države u crkvene poslove, dakle, ima u Ukrajini određenu tradiciju.

3 Vidi: https://risu.org.ua/en/index/resourses/statistics/ukr_2018 


\section{DogAĐANJA POSLIJE 2018. GODINE}

Situacija se promijenila ratnim konfliktima, od godine 2014 . Novoizabrani predsjednik Petro Porošenko, koji je i sam bio pripadnik UPC-a, počeo je (kao i neki njegovi prethodnici) tražiti od EP-a autokefalnost pravoslavlja u Ukrajini, a i parlament je donio odgovarajuću odluku. U srpnju 2018. ekumenski je patrijarh Bartolomej izjavio u pismu koje je uputio Porošenku kako namjerava ujediniti pravoslavne vjernike u Ukrajini i priznati pravoslavlju u zemlji autokefalnost. RPC je uvijek smatrala da je Ukrajina njezin "kanonski teritorij" i da EP nema pravo intervencije. A UPC, jedina Crkva koju je i EP do tada držao kanonskom, nije iznosila zahtjev da bude autokefalna. Treba pritom imati u vidu i političku situaciju zadnjih godina. Dok su sve Crkve u zemlji osuđivale rusku intervenciju i podupirale vladu, jedino UPC nije imala jedinstven stav. Mnogi ukrajinski patrioti u njoj bili su na strani svoje domovine. UPC je podupirala stav o "teritorijalnom jedinstvu Ukrajine", dakle tvrdnju kako Krim i Donbas pripadaju Ukrajini. UPC je imala vojne kapelane, i ona je sebe razumijevala kao ukrajinsku Crkvu, ne kao rusku. Liturgiju je služila na ukrajinskom (ili staroslavenskom) jeziku, njezina internet-stranica je na ukrajinskom, a dodatak MP (Moskovska patrijaršija) uz njezin naziv koji se često vidi, nije njezin službeni naziv nego joj je dodijeljen kao znak raspoznavanja, budući da se sve Crkve u Ukrajini zovu veoma slično. Zanimljivo je da se i ruski patrijarh nikad nije izjasnio za ruski (ili za ukrajinski) politički stav, znajući da bi time izgubio mnoge vjernike na jednoj ili na drugoj strani. Ukazivao je mnogo puta, i to s pravom, da je njegova Crkva jedina koja ima vjernike "s obje strane barikada". Na Krimu i u Donbasu mjesne vlasti nisu dopustile nijednu drugu pravoslavnu Crkvu do one koja je u zajednici s Moskvom. Time je UPC posebno kod ukrajinskih nacionalista dobila reputaciju antidržavne Crkve, što, međutim, ne odgovara istini.

Od rujna 2018. događaji su se dramatično razvijali. Dana 31. kolovoza došlo je do neočekivanog susreta između dvojice patrijarha, Bartolomeja i Kirila. Poglavar RPC-a putovao je u Istanbul kako bi govorio o planovima EP-a za Ukrajinu. O sadržaju tih razgovora ništa se nije saznalo, premda ih je mitropolit Ilarion, koji je bio prisutan, nakon povratka u Moskvu nazvao "bratskima i srdačnima". Od 1. do 3. rujna sastao se redoviti Sinod EP-a. Očekivalo se da će uslijediti neko rješenje za Ukrajinu, ali do toga tada nije došlo. Nekoliko dana kasnije EP je imenovala dvojicu svojih episkopa za "egzarhe" u Ukrajini. To su bili episkopi iz Kanade i SAD-a ukrajinskog podrijetla. RPC je taj čin smatrala nedopuštenom intervencijom na svojem 
teritoriju i reagirala je tako što je prekinula euharistijske veze na razini svećenika. Vjernici RPC-a su i dalje mogli sudjelovati u liturgiji svećenika i episkopa EP-a, ali ruski svećenici više nisu mogli služiti zajedno s njima. Osim toga, RPC je prekinula svako sudjelovanje u komisijama, vijećima itd. kojima je predsjedao predstavnik EP-a. Primjera radi, u Njemačkoj su ruski episkopi napustili Pravoslavnu episkopsku konferenciju, jer je mitropolit Augoustinos iz EP-a njezin predsjednik, a na ustoličenju novoga srpskog episkopa za Njemačku, sredinom rujna 2018., nijedan grčki episkop nije koncelebrirao, jer su Rusi nazočili slavlju.

Situacija se i dalje dinamično razvijala. Sinod EP-a je sredinom listopada primio u zajedništvo sve episkope nekanonskih ukrajinskih Crkava, a i njihove sljedbenike (to jest svećenike i vjernike). Važno je istaknuti da Carigrad time nije legitimirao te Crkve, dakle nije priznao crkvene strukture, nego je sve pravoslavce koji su dotad bili izvan kanonskih normi pravoslavlja primio u svoju zajednicu. Moskva je reagirala potpunim prekidom odnosa, tako da je sada i vjernicima RPC-a zabranjeno pričešćivanje u crkvama EP-a. ${ }^{4}$

Egzarsi EP-a koji su boravili u Kijevu vodili su razgovore s predstavnicima Crkava i vlasti. Bio je predviđen sabor na kojemu bi se episkopi ujedinili u novu Crkvu i izabrali njezina poglavara, koji bi onda od ekumenskog patrijarha dobio povelju (tomos) o autokefalnosti. Nekoliko su puta bili najavljivani datumi održavanja sabora, no tada on nije održan. "Patrijarh" Filaret dugo je inzistirao na toma da on bude poglavar te nove Crkve, s naslovom patrijarha. Bilo je i rasprava oko načina glasovanja na saboru, trebaju li glasovati samo episkopi ili i neki svećenici i laici, i treba li glasovanje biti tajno ili otvoreno. Naposljetku se 15. prosinca sabor ipak sastao u katedrali sv. Sofije. Predsjedavatelj je bio mitropolit Emanuel iz EP-a. Osim njega i poglavara dotadašnjih nekanonskih Crkava, mitropolita Makarija i "patrijarha" Filareta, bio je nazočan i predsjednik Porošenko. Gotovo svi episkopi nekanonskih Crkava došli su na sabor, kao i dvojica episkopa UPC-a. ${ }^{5}$ Za mitropolita je izabran episkop Epifanija iz UPC-KP-a, blizak Filaretu. Na trgu ispred crkve okupilo se mnoštvo ljudi. Njih je o rezultatu izbora izvijestio predsjednik Porošenko, koji je održao polusatni govor u kojemu je naglasio stratešku i političku

4 To znači konkretno sljedeće: U Turskoj (gdje se uvijek nalaze mnogi ruski turisti), u jednom djelu Grčke ("novi teritoriji", koji crkveno spadaju pod Carigrad), u Finskoj (tamošnja Pravoslavna Crkva je autonomna u okviru EP-a), u nekim župama u Zapadnoj Europi i na svetoj gori Atosu.

5 Formalno nisu tada više bili u sastavu UPC-a, jer ih je Ekumenska patrijaršija primila dan prije u svoju jurisdikciju. 
važnost događaja. Novoizabrani mitropolit stajao je sve vrijeme uz njega i obratio se okupljenima nakon predsjednika kratkim govorom.

Predsjednik Porošenko isto je tako pratio mitropolita Epifanija u Istanbul 5. i 6. siječnja 2019. kako bi ovaj primio tomos od ekumenskog patrijarha. U prisutnosti obojice patrijarh Bartolomej potpisao je povelju o autonomiji. Za vrijeme liturgije, u nedjelju 6. siječnja (za Carigrad Bogojavljenje, za Ukrajince Badnjak), ekumenski je patrijarh predao tomos mitropolitu Epifaniju. Time je - barem sa stajališta EP-a - Ukrajinska Crkva postala autokefalnom. Nova se Crkva zove Pravoslavna Crkva Ukrajine (PCU).

Tomos sadrži nekoliko posebnih odredaba. Službeni naziv Crkve je "Najsvetija Crkva Ukrajine", a nekoliko puta se kaže "u Ukrajini". Poglavar nosi naslov "mitropolit kijevski i sve Ukrajine", i izričito se kaže da se taj naslov ne smije mijenjati. To je očito usmjereno protiv "patrijarha" Filareta i ideje da se PCU jednom pretvori u patrijarhat. U tom je kontekstu zanimljivo da je Filaret zadržao za sebe naslov patrijarha, i da je internet-stranica njegove Crkve funkcionirala kao da se nište nije promijenilo. PCU-u je zabranjeno osnivati župe i biskupije izvan teritorije Ukrajine. To znači da se postojeće strukture, prije svega u Zapadnoj Europi, moraju podrediti EP-u, a da ukrajinske biskupije u SAD-u i u Kanadi isto tako ostaju pod njegovom jurisdikcijom. U značajnijim pitanjima crkvene, dogmatske ili kanonske naravi mitropolit se mora obratiti EP-u. Neki su kritički komentirali da to više nalikuje na autonomiju negoli na autokefalnost. Ali tomos također reflektira stav Ekumenske patrijaršije po kojemu ona ima ovlasti nad svim pravoslavcima $u$ dijaspori, tj. $\mathrm{u}$ zemljama u kojima ne postoji autokefalna pravoslavna Crkva. Tu poziciju osporavaju druge autokefalne Crkve, posebno ruska.

U pozadini stoji ekleziološki problem. Prema starocrkvenom načelu ne smiju biti dva biskupa u jednom gradu. ${ }^{6} \mathrm{U}$ Njemačkoj, primjera radi, rezidiraju pravoslavni biskupi iz raznih Crkava: Carigradske, Antiohijske, Ruske, Srpske, Rumunjske i Bugarske. Svi su ovlašteni za teritorij Njemačke, što se vidi u dijelu naslova koji neki od njih nose: “... i cijele Njemačke”. Prema tome, nije moguće odrediti tko je "pravoslavni biskup" nekog grada. U takvom se gradu pravoslavne župe nalaze u jurisdikciji "svoga" biskupa. To je nekorektna situacija iz dogmatske perspektive, a sasvim razumljiva i prirodna iz povijesne i pastoralne perspektive. Pravoslavna Crkva odlučila je da se osnivaju biskupske konferencije za takve zemlje

6 Katolička Crkva u tome isto tako nije dosljedna, budući da su neki gradovi sjedišta dvaju ili više biskupa raznih obreda. Sličan je problem s personalnim ordinarijatima, primjerice vojnim ordinarijatima u mnogim zemljama. 
kako bi se pokazalo da se radi u jednoj Crkvi, a ne o suparničkim organizacijama. Problem međutim ostaje. Dosljedna realizacija stajališta EP-a riješila bi ovaj problem, jer bi onda svi pravoslavci u takvim slučajevima bili njoj podređeni. Tada bismo imali korektne odnose, ali bi se ruski, srpski, rumunjski i bugarski vjernici i svećenici nalazili pod biskupima EP-a, konkretno: pod grčkim biskupima - što bi predstavljalo nov problem.

RPC je događanja oko tomosa zapravo ignorirala. Ona je tvrdila da sve ono što se događalo nema za nju značenje, a smatrala je UPC i dalje jedinom kanonskom Crkvom u Ukrajini. Ukazivala je na izjave drugih pravoslavnih Crkava i pojedinih biskupa koji su izrazili sumnju prema akcijama EP-a. Zaista je od najvećeg značenja pitanje kako će se držati druge mjesne Crkve. Dosad one očito pokušavaju ostati u jedinstvu i s Carigradom i s Moskvom. EP je najavila da ce o svojim odlukama informirati druge autokefalne Crkve pismom i da će tražiti da i one priznaju PCU. Bude li jedan dio pristupio Moskvi, a drugi dio Carigradu, tako da nastanu dva tabora, onda ce to najvjerojatnije voditi u raskol unutar pravoslavlja koji može trajati i vjekovima. Ako druge Crkve uspiju držati kontakt s objema stranama, takav se raskol može izbjeći. Grčka je Pravoslavna Crkva, 12. listopada 2019., priopćila da će priznati PCU, kao prva nakon EP-a. Očekuje se da će to biti do kraja 2019. RPC je najavila da će u tom slučaju prekinuti euharistijske veze i s Grčkom Crkvom.

Drugi čimbenik koji će odlučiti o sudbini pravoslavlja u Ukrajini su brojke, naime, broj biskupa, svećenika i vjernika iz UPC-a koji će prijeći u PCU. Dosad ih nije mnogo. Od 90-ak biskupa UPC-a njih dvojica sudjelovala su u Sinodu 15. prosinca. To znači da je episkopat UPC-a po broju dva puta veći od episkopata PCU-a. Teže je govoriti o župama i vjernicima jer nema točnih podataka. Od osnivanja PCU-a određeni je broj župa UPC-a prešao k njima. Okolnosti tih prijelaza nisu uvijek jasne, jer postoje tvrdnje u UPC-u da se radilo o nasilnim akcijama. Navodno, jedan ili dva autobusa puni mladih momaka došli bi u mjesto u kojemu crkva pripada UPC-u. Za vrijeme ili prije početka liturgije oni bi išli u crkvu i tražili glasovanje o pripadnosti dotične župe, zastrašili župnike, tvrdili da nema ni jednoga glasa protiv, doveli bi svojeg svećenika i tako silom preuzeli crkvu i župu. Na internetu se mogu naći videosnimke takvih događanja, no nije moguće ustanoviti koliko ih ima. Dojam je dosad da je broj župa koje prelaze u novu Crkvu veoma malen (oko 500), čak ako se ti sporni slučajevi smatraju dobrovoljnim prelascima.

Jedan važan čimbenik u svemu tome je držanje ukrajinske države. Ona je u svemu igrala iznimno značajnu ulogu. Predsjednik Porošenko nije bio prvi koji je tražio od EP-a priznavanje auto- 
kefalnosti - to su činili i drugi predsjednici prije njega. Isto tako je Verhouna rada, dakle parlament zemlje, donijela rezoluciju u kojoj je tražila autokefalnu Crkvu. Ulogu predsjednika države na skupu 15. prosinca već smo spomenuli. Isto tako, on je 6. siječnja 2019., s mitropolitom Epifanijom otišao u Istanbul, na potpisivanje povelje, a idućih je dana s mitropolitom Epifanijom obilazio razne biskupije u Ukrajini, kako bi ondje zajedno predstavili tomos. U govorima je često naglašavao strateško i političko značenje tog čina i time jasno pokazao da se za njega ne radi toliko o crkvenom koliko o političkom događaju. Krajem ožujka 2019. održani su predsjednički izbori u zemlji te je umjesto Porošenka izabran Vladimir Zelenski, kojega očito ne zanima crkvena problematika. Nakon njegova izbora prelazi iz drugih jurisdikcija u PCU praktički su prestali.

Lokalne vlasti su na početku u znatnoj mjeri pokušavale utjecati na stanovništvo, u smislu prelaženja u novu Crkvu. Država je organizirala prosvjede protiv biskupa UPC-a koji su se izjasnili za ostanak u svojoj Crkvi i koji su odbili doći na skup 15. prosinca. U nekim slučajevima pretraživani su njihovi stanovi i uredi. Bilo je prijetnji da će država UPC-u oteti dva značajna i ugledna samostana, Kijevsku pećinsku lavru i Počajivsku lavru, i predati ih novoj Crkvi. Njihove zgrade su u vlasništvu države, koja je ih dala UPC-u na raspolaganje, kao što je dala druge crkve i samostane drugim Crkvama. U skupinu mjera protiv UPC-a spada i zakon koji je Rada prihvatila i po kojemu UPC mora promijeniti svoje ime. Prema tom zakonu vjerska organizacija koja je povezana s vjerskom organizacijom u inozemstvu, "u državi koju je Rada proglasila agresorom", ne smije se zvati ukrajinskom. UPC je prosvjedovala, ali vlasti su tražile od nje da u roku od šest mjeseci, do sredine 2019. godine, izabere novo ime. Vrhovni sud Ukrajine poništio je zakon, ali je to spadalo u pokušaje ukrajinske politike da prikaže UPC kao "rusku", "moskovsku" Crkvu. Vidjeli smo već da to ne odgovara istini. Međutim, u situaciji rata između Rusije i Ukrajine to je način na koji se pokušava ocrniti UPC. Čini sa da se situacija smirila nakon formiranja nove vlade.

Važan čimbenik za budućnost pravoslavlja u Ukrajini je način na koji će se ostale pravoslavne Crkve u svijetu odnositi prema ovim zbivanjima. Dosad je samo Moskva prekinula odnose s Ekumenskom patrijaršijom, dok ova sa svoje strane ništa nije poduzela. Sve ostale autokefalne Crkve zasad održavaju odnose i s jednom i s drugom patrijaršijom. Bilo je nekoliko kritičnih komentara, čak od episkopa EP-a, ${ }^{7}$ ali dosad nije bilo nikakvih akcija. Mitropolit Sawa, koji

$7 \quad$ Poznati teolog Kallistos Ware izjasnio se $\mathrm{u}$ tom smislu. 
je na čelu Poljske Pravoslavne Crkve, dao je do znanja da njegova Crkva neće ispuniti molbu EP-a da prizna novu Crkvu. Gruzijska Crkva razmatrala je ovu temu u Sinodu, no dosad bez rezultata. Sinod Pravoslavne Crkve Cipra priznao je pravo EP-a da se miješa u ukrajinske crkvene poslove, ali samo u smislu nadilaženja konflikata i raskola. Ako to pitanje ne bude riješeno nakon određenog vremena, Ciparska Crkva zahtijevat će općepravoslavni koncil. Isto su tražili i Rumunji. Ekumenski patrijarh je, međutim, odbacio tu ideju. Najnovija odluka je ona Grčke Crkve. Teško je predvidjeti kako će se situacija dalje razvijati.

Srpski je patrijarh, krajem 2018., upozorio ekumenskog patrijarha kako ne bi bilo dobro kad bi priznao ukrajinsku autokefalnost. Za srpsko su pravoslavlje pitanja Makedonije i, u znatno manjoj mjeri, Crne Gore goruće teme. Makedonija je jednostrano objavila crkvenu autokefalnost 1967., uz pomoć tadašnjega jugoslavenskog režima. No nijedna pravoslavna Crkva nije priznala tu autokefalnost. Nakon kraja komunizma Srpska pravoslavna Crkva mogla je imenovati biskupe za Makedoniju, no vlasti u Skopju zabranili su im ulazak u Makedoniju ili boravak u zemlji; mitropolit Jovan čak je duže vrijeme bio u makedonskom zatvoru, jer je Makedonska Pravoslavna Crkva zaštićena Ustavom. Budući da se odnosi između Grčke i Sjeverne Makedonije normaliziraju, crkveno pitanje će opet doći na dnevni red. Danas se ne čini da će Srpska ili Grčka Crkva promijeniti svoj stav, ali stabilizacija političkih odnosa značila bi i nov kontekst za to pitanje. U Crnoj Gori situacija je drugačija, jer je SPC prisutna u zemlji. Nekanonska Crnogorska Crkva mnogo je manja, a prije svega je u potpunosti nekanonska; njezin je poglavar dispenzirani svećenik koji je više puta mijenjao jurisdikcije i najvjerojatnije nema valjano biskupsko zaređenje, tako da se ne može govoriti o ozbiljnom projektu (za razliku od makedonske hijerarhije, koja je bez sumnje nekanonska i prisutna u cijeloj zemlji). No nakon ukrajinskih događanja crnogorski predsjednik je izjavio da će i on tražiti autokefalnost za "svoju" Crkvu.

\section{KONCEPT AUTOKEFALNOSTI I EKUMENSKA DIMENZIJA}

Iza cijelog konflikta stoji problem unutar pravoslavlja koje nije postiglo suglasnost o pitanju kako se autokefalnost može steći. Postavlja se pitanje je li ekumenski patrijarh prvi nadležan po potanju autokefalnosti, ili pak "Crkva majka", dakle ona Crkva čiji jedan dio želi postati autokefalan. Povijesno, gotovo u svim slučajevima Carigrad je bio i Crkva majka: Ruska, Grčka, Srpska, Bugarska i Rumunjska 
Crkva bile su pod jurisdikcijom EP-a prije nego što su postale autokefalne. To vrijedi, premda pod drugim okolnostima, i za Albansku Crkvu. U slučaju Slovačke i Poljske Crkve stvari stoje malo drugačije.

Kad pogledamo autokefalne Crkve, možemo zamijetiti tri skupine: jednu čine Crkve koje su već u antici postale samostalne: Carigradska, Aleksandrijska, Antiohijska, Jeruzalemska patrijaršija i Crkva na Cipru. Osim potonje, sve su živjele i žive kao manjine u muslimanskom okruženju (Jeruzalem danas u židovskom). Njihova jurisdikcija obuhvaća nekoliko država, u slučaju Aleksandrije čak cijelu Afriku. Iz tih razloga one nisu razvile blizak odnos prema državi, ni prema naciji (premda je kod njih bila važna najprije grčka nacionalna identifikacija, no danas su uglavnom multinacionalne).

Drugu skupinu autokefalnih crkava čini samo jedna, naima RPC, koja je u 15. stoljeću postala autokefalnom. Ona je stoljećima bila "imperijalna" Crkva, u smislu da se njezina jurisdikcija uvijek odnosila ne teritorij ruske države, dakle Ruskoga Carstva, Sovjetskog Saveza ili Ruske Federacije. Nakon raspada Sovjetskog Saveza RPC je desetljećima održavala jurisdikciju. Devedesetih je godina postojao konflikt s EP-om o pravoslavlju u Estoniji, ali inače je jurisdikcija RPC-a nad tim teritorijem do prošle godine bila neosporena, ${ }^{8}$ čak i od strane EP-a.

Treću skupinu čine autokefalne Crkve koje su nastale u 19. i 20. stoljeću, gotovo sve na Balkanu. Grčka, Srpska, Bugarska, Rumunjska i Albanska Crkva nastale su kao dio nacionalnih projekata. Tijekom raspadanja Osmanskog Carstva formirale su se neovisne nacionalne države. Njihove su Crkve bile pod Carigradom, kao što su i politički pripadale Carigradu, to jest osmanskoj državi. U logici političke samostalnosti bila je i crkvena samostalnost, dakle autokefalnost. Nju te Crkve najčešće nisu stekle odmah, nego nakon dužih rasprava s EP-om, koji se nije htio odreći tih dijeceza. Katkad te Crkve EP desetljećima nije priznavao.

Slučaj Ukrajine treba tumačiti u tom kontekstu. Nakon raspada imperijalne države, novonastala država zahtijeva i svoju Crkvu. To je više nacionalni negoli crkveni projekt, ali tako je bilo i u slučaju ostalih pravoslavnih crkava koje su postale autokefalne od 19. stoljeća. Zbog toga je i jaka politička potpora ukrajinske autokefalnosti razumljiva, premda ona ne odgovara crkvenim načelima.

Koncepcija autokefalnosti ostavlja svakoj mjesnoj Crkvi velik prostor za izražavanje svojih lokalnih tradicija. To se odnosi na litur-

8 To se ne odnosi na Gruziju i Armeniju, koje od starih vremena imaju svoju neovisnu pravoslavnu (Gruzija), odnosno staroorijentalnu (Armenija) Crkvu. 
gijski jezik, na kalendar, na mnoge oblike pobožnosti, ali posebno se pokazuje u upravi Crkve. Način izbora biskupa i prvog poglavara (patrijarha, nadbiskupa, mitropolita) u nadležnosti je svake Crkve. U Rusiji Sinod (dakle skupina biskupa pod patrijarhom) određuje tko će gdje postati biskup, dok u Rumunjskoj poseban skup svećenika i laika, koji su čak u većini, bira svog biskupa (koji mora dobiti potvrdu od Sinoda). Osnivanje novih biskupija, odnosi s državom, proglašenje svetaca - sve je to u nadležnosti autokefalnih crkava. One nemaju pravo donošenja odluka o pitanjima vjere i dogme, što je rezervirano za ekumenski koncil. Budući da je zadnji koncil koji pravoslavne crkve priznaju kao takav bio Drugi nicejski 787. godine (dakle 7. koncil po katoličkom računanju), ne postoji općeprihvaćeni stav o pitanjima ekleziologije ili sakramentologije. Neki pravoslavni teolozi čak tvrde da je "teologija" naučavanje o Bogu i da su prema tome pitanja crkvenog ustrojstva ili čovjekova spasenja, kao i etičke teme, od drugorazrednog značenja. U svakom slučaju, crkvena struktura pravoslavlja omogućuje veliku autonomiju lokalnih crkava, ali smeta razvoju dogmatskih odredaba.

Pravoslavne su se crkve od sredine 20. stoljeća potrudile organizirati Svepravoslavni sabor kako bi riješile pitanja koja su nastala u moderno doba ili u kojima odgovori iz antike više nisu dostatni u praksi. Taj Sabor se sastao 2016. na Kreti, nakon priprema koje su trajale više od 60 godina. Međutim, predstavnici četiriju crkava (od njih 14) nisu došli: Ruska Pravoslavna Crkva, Antiohijska, Bugarska i Gruzijska Crkva iz raznih su razloga odustale. U pripremi Sabora bilo je dogovoreno da se raspravlja samo o temama o kojima bi se prethodno postigao konsenzus. Tako je popis od stotinjak tema reduciran na njih šest. Pitanje dobivanja autokefalnosti nije bilo u toj skupini, premda postoji svijest u pravoslavlju da se radi o najaktualnijoj temi koja zahtijeva hitna rješenja. Ali crkve se nisu mogle dogovoriti unaprijed tko bi bio nadležan za davanje autokefalnosti. Prema tome, EP je u Ukrajini postupila bez suglasnosti čak i o samom postupku (tko daje autokefalnost?), a o samom pitanju (autokefalnost za Ukrajinu) da se i ne govori.

U prvom tisućljeću, dakle prije velike šizme, sjedinjena Crkva (naravno bez ruske i drugih modernih crkava) brojala je jedan patrijarhat više, naime Zapadni, Rimski. Do pape Benedikta XVI. svi su pape nosili titulu "patrijarha Zapada", premda ona zapravo više ništa nije značila. To je bio i razlog zbog kojeg se Benedikt XVI. odrekao te titule. No za sve ozbiljne pravoslavne teologe neupitno je da bi u slučaju da se crkve ponovno ujedine Rimska Stolica imala prvo mjesto; Carigrad je naslijedio to mjesto kad se Rim, po istočnom tumačenju, odvojio od Crkve. Kao što je poznato, pravoslavni 
Istok nije spreman prihvatiti zapadne dogme o papi koje su nastale u drugom tisućljeću. ${ }^{9}$ Međutim, ni o pitanju što je zapravo bila realnost prvog tisućljeća, ne postoji suglasnost. Nema sumnje da je rimsko prvenstvo lagano raslo, a prvi pokušaj jasnog zahtijevanja prvenstva nalazimo kod Lava I. u 5. stoljeću. Prava koja su rimski biskupi kasnije tražili za sebe uglavnom nisu bila priznata na Istoku. Istočnoj Crkvi uvijek je veoma stalo do toga da pridobije suglasnost papa u dogmatskim pitanjima, da papinski izaslanici budu na koncilima i da je "pentarhija", dakle isto teološko mišljenje svih pet patrijarhata dokaz za to da je neko naučavanje ispravno. Ali Istok nikad nije poznavao ni priznao pravnu, jurisdikcijsku moć Rima izvan Zapadnog patrijarhata.

Papa Franjo naglašava važnost autonomije lokalnih crkava. U Katoličkoj Crkvi danas to se odnosi uglavnom na biskupske konferencije. One su nastale tek u 19. stoljeću. U starom kodeksu (CIC 1917.) bile su spomenute kao skupovi biskupa s mitropolitom, dakle blizu starocrkvenoj praksi, no očito taj model nije funkcionirao. Život Crkve u modernoj državi zahtijevao je drugi način samoorganiziranja, naime skup svih biskupa u jednoj državi. Drugi vatikanski koncil dao je biskupskim konferencijama neka prava, a u novom Kodeksu Kanonskog Prava ona su utemeljena. Problem je što se biskupi ponekad boje da bi njihova biskupska vlast mogla biti ograničena odlukama biskupske konferencije, premda ona nema jurisdikciju nad biskupima, jer svaki biskup slobodno odlučuje hoće li odluke biskupske konferencije staviti na snagu u svojoj biskupiji. Ima slučajeva u kojima biskupi koji su bili nadglasani u svojoj biskupskoj konferenciji, odluku konferencije nisu primijenili za svoju biskupiju.

Velika je razlika, međutim, u tome što u pravoslavlju ne postoji pravna prednost jedne crkve ili institucije u odnosu na druge. EP je priznata kao prva u kanonskom redoslijedu, ali to ne podrazumijeva njezinu ingerenciju nad drugim crkvama. One su potpuno neovisne, ali sve zajedno se vide kao jedna Pravoslavna Crkva. I zaista, u pitanjima doktrine ili liturgije nema razlika među njima - teološke debate postoje, ali se odigravaju uglavnom unutar crkava. U svakom sukobu te vrste ima pristaša jedne i druge strane u svakoj crkvi. Jedina, ali u našem slučaju odlučujuća sporna točka je interpretacija tog prvog mjesta u kanonskom redoslijedu, dakle obujam prava ekumenskog patrijarha. To se tiče i njegovih prava u zemljama u kojima nema samostalne Pravoslavne Crkve, dakle u dijaspori, ali i

9 Ovdje treba navesti poznatu izreku tadašnjeg profesora Ratzingera, koju je on kao kardinal ponovno objavio: "Rim ne smije od pravoslavnog Istoka tražiti više nego što je bila realnost u prvom tisućljeću.” 
prava dodjeljivanja autokefalnosti. Djelovati u situaciji u kojoj se svi ne slažu oko toga kako treba i kako se može djelovati je naravno problematično. Slučaj Ukrajine pokazuje kako u pravoslavlju nedostaje moderatorska uloga prvenstva - onog prvog, koji bi ne samo autoritetom nego i razumijevanjem onoga što je bitno za Crkvu u danoj situaciji mogao moderirati proces rješavanja konflikta.

Može li Katolička Crkva iskoristiti iskustva pravoslavlja u tom kontekstu za svoje ekleziološke ideje? Kako je u Pravoslavnoj Crkvi sinodalnost razvijena, ali uloga prvenstva ponekad nedostaje, tako je u Katoličkoj Crkvi prisutno prvenstvo, čak veoma jako, ali sinodalne procese tek treba razviti. Za ekumenska nastojanja trebat će naći takav oblik Crkve da pravoslavci mogu očuvati svoju tradiciju, a da katolici interpretiraju prvenstvo rimskog biskupa na način da ono ostaje prvenstvo, ali da bude prihvatljivo za pravoslavlje. A unutar Katoličke Crkve treba nadići pretjerani centralizam, koji je dugo vremena prevladavao, a protiv kojega se papa Franjo s pravom angažira. Autokefalnost, u smislu potpune samostalnosti recimo biskupskih konferencija, teško se može uskladiti s katoličkom tradicijom. Ali autokefalnost u smislu većeg utjecaja mjesne Crkve na izbor biskupa, dakle na samo biranje svojeg poglavara (auto-kefalnost), nešto je što je sasvim moguće i u Katoličkoj Crkvi. Na nama je teolozima dublje promišljati o tome. Pogled na druge crkvene tradicije, u ovom slučaju na pravoslavnu, može za to biti od velike koristi.

\section{ZAKLJUČAK}

Svi se teolozi slažu da u ekleziologiji leži najvažnija, možda i jedina zaista bitna razlika između Katoličke Crkve i pravoslavlja. Isto tako je jasno da se strukture dviju Crkava razlikuju u velikoj mjeri. Međutim, zadnjih godina su se i u katoličkoj teologiji i u ekumenskim nastojanjima razvila mišljenja kako bi se prvenstvo, a posebno papinsko, moglo tumačiti na način koji daje sinodalnim elementima više značenja. To je u interesu Katoličke Crkve, i papa Franjo jasno i često naglašava takve ideje. Ali to bi na kraju značilo i mogućnost približavanja između Katoličke Crkve i pravoslavlja.

Pitanje crkvenih struktura u pravoslavlju u Ukrajini pokazuje veoma drastično tu načelnu razliku između dviju Crkava. Pravoslavne Crkve sačuvale su u teološkim pitanjima visok stupanj jedinstva, što iznenađuje s katoličkog stajališta, posebno stoga što one nemaju središnju instanciju koja bi služila očuvanju tog jedinstva, i što od godine 787. nisu imale sabor koji bi odlučivao o dogmatskim pitanjima. Doista, sve Crkve koje su uključene u te rasprave oko 
Ukrajine - EP, RPC, PCU i ostale - nimalo se ne razlikuju u pitanjima vjere. Cijela ta rasprava odigrava se oko crkvenih struktura, ili - ako se želi biti točniji - oko moći i prevlasti. To je razlog što oko strukturalnih, eklezioloških pitanja ne postoji jednoglasno mišljenje unutar pravoslavlja. Odluka EP-a da poduzme korak od takvog značenja kakvo je priznanje autokefalnosti, znači dakle postupati $u$ inače nejasnoj i neriješenoj situaciji. Jasno je da su posljedice morale biti dalekosežne.

Ostaje otvorenim pitanje može li pravoslavni ekleziološki nauk pridonijeti boljem katoličkom razumijevanju vlastite ekleziologije. Čini se da trenutačni problemi koji su nastali zbog ukrajinskoga crkvenog pitanja više ukazuju na prednost načela prvenstva. Neki pravoslavni teolozi već su se i izjasnili kako bi pravoslavno prvenstvo, ispravno shvaćeno, mogao biti od pomoći u ovoj situaciji; dakle prvenstvo koji bi omogućilo zajedničko rješenje ovog problema kroz dijalog i bratsku raspravu. Valjalo bi, međutim, ta pitanja razmotriti i na apstraktnoj teološkoj razini, dakle bez koncentriranja samo na konkretnu situaciju, i upitati se koliko bi ona mogla pridonijeti katoličkoj teologiji. Onda bi se mogli vidjeti elementi koji su u stanju ponuditi zanimljive ideje i za katoličko teološko razmišljanje, posebno u situaciji u kojoj se Katolička Crkva i njezina teologija danas nalaze.

\section{CONCEPT OF AUTOCEPHALIA IN ORTHODOXY AND CURRENT CONFLICT BETWEEN CONSTANTINOPLE AND MOSCOW}

\section{Summary}

During 2018 and 2019, church circumstances in Ukrainian Orthodoxy changed significantly. With considerable assistance of that-time Ukrainian government, the Patriarchate of Constantinople unilaterally declared the newly created "Orthodox Church of Ukraine" (OCU) an autocephalous, i.e. independent. The Russian Orthodox Church, however, regards Ukraine as its "canonical territory" and does not recognize the OCU as valid, but calls it a schismatic organization. In response to the proclamation of the OCU's autocephaly, the Russian Church terminated the Eucharistic communion with Constantinople. There is even a danger of schism that would span all Orthodoxy, depending on how other Orthodox churches would react. The current debate is due to the fact that in Orthodoxy there is no consensus on how one Church can become autocepha- 
lous. Accordingly, there are ecclesiological problems in the background that have not been resolved. The issue of autocephaly is an Orthodox issue, but for the Catholic Church and theology, especially in its current position, it is important to think about the relationship between synodality and primacy.

Keywords: Ukraine, Constantinople, Orthodox Church, autocephaly, ecclesiology 